This is an open access article under the CC-BY-SA

license

\title{
Penonjolan Identitas Melayu Islam oleh Pemerintah dan Masyarakat Riau
}

\section{Hasse Jubba ${ }^{1}$, Muhammad Rafi ${ }^{2}$, Zuly Qodir ${ }^{3}$}

hasse@umy.ac.id,m_rafi@yahoo.com,zuly_qodir@yahoo.com

${ }^{1}$ Pasca Sarjana Universitas Muhammadiyah Yogyakarta

${ }^{2}$ Jusuf Kalla School of Government, Universitas Muhammadiyah Yogyakarta

3Pasca Sarjana Universitas Muhammadiyah Yogyakarta

DOI: https://doi.org/10.22219/sospol.v7i1.12822

\begin{abstract}
This article aims to explain the efforts of the government and the people of Riau in promoting Islamic Malay identity. Through observation, literature study and documentation study, several efforts were found to support the continuity of Malay identity amidst various challenges today. The concept of identity politics is used to analyze the above problems and it is found that there are three construction processes of a social identity which include legitimate identity, resistant identity, and project identity. This paper finds the finding that the efforts to emphasize Islamic Malay identity by the government and the people of Riau are carried out in three stages. First, efforts to legitimize the Malay identity through the formation of the Riau Customary Institution (LAM) which is dedicated to protecting and preserving the heritage of the Malay symbol and in cooperation with the Riau Provincial Government. Second, efforts to fight against the negative stigma attached to Malay culture in the past. Third, the identification of Malay as Islam and vice versa through the promotion of Malay as an effort to ward off previous negative views and to affirm the existence of Islamic Malay culture in Riau.
\end{abstract}

\begin{abstract}
Abstrak
Artikel ini bertujuan menjelaskan upaya dari pemerintah dan masyarakat Riau dalam mengedepankan identitas Melayu Islam. Melalui observasi, studi kepustakaan serta studi dokumentasi ditemukan beberapa upaya yang mendukung keberlangsungan identitas Melayu di tengah berbagai tantangan saat ini. Konsep politik identitas digunakan untuk menganalisis persoalan di atas dan ditemukan adanya tiga proses konstruksi sebuah identitas sosial yang meliputi identitas legitimasi, identitas resisten, dan identitas proyek. Tulisan ini menghasilkan temuan bahwa upaya penonjolan identitas Melayu Islam oleh pemerintah dan masyarakat Riau dilakukan melalui tiga tahapan. Pertama, upaya legitimasi identitas Melayu melalui pembentukan Lembaga Adat Melayu (LAM) Riau yang didedikasikan untuk melindungi dan memelihara warisan simbol Melayu dan bekerjasama dengan Pemerintah Provinsi Riau. Kedua, upaya perlawanan terhadap stigma negatif yang disematkan pada budaya Melayu di masa lalu. Ketiga, pengidentifikasian Melayu adalah Islam dan sebaliknya melalui promosi Bahasa Melayu sebagai upaya untuk menepis pandangan negatif sebelumnya dan menegaskan eksistensi budaya Melayu Islam di Riau.
\end{abstract}

\author{
Keywords \\ Budaya, Identitas, Islam, Melayu, \\ Rian
}

\section{Article History}

Received November 6, 2020

Revised April 10, 2021

Accepted April 12, 2021

Published April 15, 2021

\section{Corresponding Author}

Hasse Jubba. Pasca Sarjana Universitas Muhammadiyah Yogyakarta, Jl. Brawijaya, Bantul, Yogyakarta. 55183 
license

\section{Pendahuluan}

Isu tentang politik identitas telah berlangsung cukup lama dan banyak terjadi di berbagai wilayah. Pada mulanya, isu politik identitas berawal di Amerika Serikat (AS) pada tahun 1970-an, dimana ketika itu dihadapi suatu masalah terkait perbedaan gender, feminism, ras, etnisitas, dan kelompok-kelompok sosial lainnya yang merasa tertindas, dan dilecehkan. Pada perkembangannya isu politik identitas tidak hanya terjadi di AS, tetapi juga di berbagai belahan dunia lainnya, termasuk Indonesia. Politik identitas di Indonesia lebih spesifik berfokus pada masalah ras, budaya, politik dan preferensi lokal yang diungkapkan oleh elit melalui akumulasi kepentingan masing-masing. Gerakan Pemekaran daerah dapat dilihat sebagai salah satu bentuk politik identitas, yang didalamnya memuat berbagai masalah keadilan dan pembangunan daerah yang menjadi pusat perdebatan politik lokal berdasarkan etnis suatu wilayah, tidak terkecuali etnis Melayu (A. Abdullah, 2017; Erman, 2018). Secara umum, etnis Melayu di negara-negara Asia Tenggara sadar akan tantangan yang mereka hadapi bersama, dan tidak seperti orang Melayu di Indonesia yang memiliki individualitas sendiri dalam menunjukkan budaya mereka, kelompok etnis Melayu di Indonesia terikat bersama di daerah masing-masing. dan tidak memiliki kesatuan psikologis yang sama untuk dilawan. Sebagai hasil dari perkembangan lokal ini, identitas Melayu di Indonesia telah menyempit dan berkembang secara mandiri. Preferensi identitas Melayu sering didikte oleh keadaan yang mereka hadapi dan berubah sesuai dengan tuntutan zaman. Tekanan budaya dan politik oleh pemerintah Orde Baru telah menyebabkan melemahnya komunitas Melayu di Indonesia. Situasi ini tercipta karena pemerintah Orde Baru melakukan homogenisasi budaya yang berkontribusi pada Jawanisasi, Identitas Melayu terkikis sampai reformasi datang (Alfarabi et al. 2019).

Masa transisi adalah pergeseran dalam struktur dan pemerintahan Indonesia di bawah rezim Orde Baru. Kebijakan yang secara tradisional bersifat "top-down" telah mulai digantikan oleh proses otonomi daerah yang memungkinkan daerah memiliki kekuasaan untuk mengatur diri mereka sendiri. Masa Reformasi telah memberi ruang lebih banyak bagi rakyat Indonesia untuk mendapatkan dukungan bagi kebijakan pusat dan nasional. Partisipasi masyarakat dalam penetapan kebijakan nasional dan lokal adalah sistem politik demokrasi langsung yang lahir dari reformasi. Sistem politik pemilihan langsung memungkinkan para pemilih untuk aktif dalam memutuskan siapa yang perlu dianggap sebagai perwakilan kota. Dalam konteks ini, identitas daerah menjadi lebih kental karena setiap daerah ingin dipimpin oleh putra-putra daerahnya. Kesadaran sebagai tuan rumah di negara mereka sendiri merupakan masalah yang mengikuti usia kemerdekaan di masa reformasi. Situasi ini membuat identitas regional menjadi kompetitif dan menjadi topik yang sedang dibahas dalam konteks kebijakan lokal. Oleh karena itu, kelahiran strategi otonomi daerah dan sistem politik pemilihan langsung telah membantu meningkatkan kesadaran akan identitas Melayu (Alfarabi, 2019).

Meskipun demikian, kelangsungan hidup supremasi budaya Melayu merupakan tantangan besar, karena meskipun masih kuat, posisi Melayu saat ini kurang strategis dan pengaruhnya mulai menurun (I. Abdullah, 2017). Hal ini terlihat pada beberapa studi terdahulu yang mengulas tentang lemahnya supremasi budaya Melayu, sebagaimana tampak dari kegagalan seorang putra Melayu untuk menjadi Gubernur Riau pada 1985 karena adanya penolakan yang dilakukan oleh Presiden Soeharto (Rozi, 2018). Selain itu, meskipun era reformasi telah memungkinkan penduduk Riau Melayu untuk terus menunjukkan kehadiran mereka di daerah mereka sendiri (Alfarabi et al. 2019; Alfarabi, 2019; Alfarabi, Antar Venus, Nuryah Asri Syafirah, 2019), pada praktiknya penduduk Melayu Riau belum mampu mengelola dan memanfaatkan berbagai posisi strategis dalam kekuasaan. Sebagai contoh, di Kabupaten Indragiri Hilir, etnis Bugis memiliki posisi strategis di berbagai bidang, khususnya dalam badan legislatif. Padahal di wilayah tersebut, Etnis Bugis adalah pengungsi etnis, dengan total populasi 150.816 jiwa, dan menempati peringkat ketiga di antara kelompok etnis Melayu dan Banjar (Hapsa, 2019). Selain itu berbagai studi terdahulu juga 
license

memberikan kerangka awal mengenai pentingnya budaya Melayu bagi masyarakat Riau. Pada masa pemerintahan Soeharto, identitas kultural Melayu pernah mengalami kondisi terpuruk, sebagaimana terlihat dari homogenitas ekspresi kultural masyarakat. Hal ini tampak dari peminggiran berbagai simbol-simbol kultural seperti ornamen pakaian, rumah adat, Bahasa dan identitas lainnya (Affandi, 2018; Syu'ib, 2017).

Berangkat dari paparan diatas, dengan menggunakan politik identitas sebagai kerangka konseptual, tulisan ini berupaya untuk menjelaskan berbagai upaya dari pemerintah dan masyarakat Riau dalam mengedepankan identitas Melayu Islam agar dapat menjadi ciri khas dari Provinsi Riau. Secara umum terdapat cukup banyak definisi mengenai Politik Identitas. Menurut Heywood (2014) Politik Identitas adalah sebuah gaya politik yang yang berusaha melawan marginalisasi kelompok dengan menganut sebuah rasa identitas bersama yang positif dan asertif. Selanjutnya, menurut Morowitz dalam Prayetno (2016) politik identitas merupakan suatu cara untuk memberikan garis yang tegas dalam menentukan siapa saja yang termasuk anggota kelompok dan siapa saya yang bukan bagian dari kelompoknya. Mengingat garis-garis demarkasi tersebut tidak dapat diubah, maka status keanggotaan tampak bersifat permanen. Menjadikan identitas etnis sebagai komoditas politik merupakan langkah mempengaruhi pihak lain agar dapat memenuhi keinginannya. Politik identitas menekankan pada adanya upaya untuk menjadikan perbedaan sebagai label diri atau kelompok, termasuk pada etnis di Indonesia. Upaya ini penting dilakukan dalam rangka mencari jalan mempertahankan identitas dan keberlangsungan kelompok. Terkait dengan ini, persoalan penggunaan identitas untuk kepentingan lain bukanlah hal baru. Sebab, identitas merupakan sumber makna yang utama sehingga apa yang dilakukan seseorang berlandaskan pada apa yang diyakini (Hemay \& Munandar, 2015; Salim, 2015).

Berkaitan dengan pembentukan identitas, menurut Manuel Casteels, sebagaimana dikutip dalam Salim (2015), terdapat tiga proses pembentukan dalam membangun sebuah identitas. Pertama, identitas legitimasi (legitimirzing identity) yang dapat dipahami sebagai citra lembaga yang mengatur masyarakat yang merasionalisasi dan mempertahankan hegemoni atas aktor sosial, seperti lembaga negara yang berupaya meningkatkan identitas nasional anggota masyarakat. Bahkan, organisasi telah memperoleh kredibilitas untuk melakukannya. Kedua, identitas resisten (resistance identity) yaitu sebuah Siklus pembentukan identitas oleh anggota sosial yang berada di bawah tekanan karena dominasi dan stereotip oleh pihak lain untuk membentuk oposisi dan penciptaan identitas yang berbeda dari mereka yang memerintah, dengan pandangan terhadap keberadaan suatu komunitas. Ketiga, identitas proyek (project identity) yang merupakan sebuah Identitas di mana anggota budaya membentuk identitas baru yang dapat menentukan posisi baru dalam masyarakat dan mengubah struktur masyarakat secara keseluruhan. Paparan mengenai proses pembentukan identitas sebagaimana telah dijelaskan diatas akan dipakai oleh penulis guna menjelaskan upaya pemerintah dan masyarakat Riau dalam menonjolkan identitas Melayu Islam.

\section{Metode}

Penelitian ini merupakan penelitian kepustakaan yang bersifat deskriptif-eksploratif. Mendeskripsikan sekaligus mengeksplorasi gagasan tentang politik identitas Melayu Riau dalam mewujudkan budaya Melayu yang berintegritas. Penelitian ini menggunakan metode kualitatif dengan langkah menjawab pertanyaan di dalam rumusan masalah yang telah ditetapkan berdasarkan bacaan dan interpretasi terhadap data-data yang berhubungan dengan tema yang diteliti, terdiri dari sumber-sumber primer dan sekunder. Sumber-sumber primer terdiri dari jurnal ilmiah, prosiding, buku, majalah, surat kabar dan lain sebagainya yang secara langsung mengacu pada tema penelitian. Sedangkan sumber-sumber sekundernya berupa sumber-sumber tersebut di atas, namun tidak berkaitan langsung dengan tema (Hermawan, 2019).

Teknik pengumpulan penelitian ialah membaca, mencatat, menyeleksi data dan mengkategori data. Secara rinci, kegiatannya diawali dengan membaca literatur-literatur yang terkait 
license

dengan penelitian, kemudian dilanjutkan dengan mencatat bahan-bahan tersebut untuk memperluas informasi yang diperlukan. Tahap selanjutnya, diadakan penyeleksian data yang telah diperoleh. Sebagai tahap akhir dilakukan kategorisasi data, untuk dimasukkan pada sub-sub pembahasan yang tepat (Albi Anggito, 2018). Untuk mengkaji data yang telah diperoleh, digunakan analisis deskriptif kualitatif dengan cara mereduksi data, menyajikan data dan menarik kesimpulan. Perhatian utama dalam penelitian ini akan diarahkan pada kajian politik identitas melayu riau dalam mewujudkan budaya melayu yang berintegritas.

\section{Hasil dan Pembahasan}

Paparan pada bagian ini merupakan elaborasi terhadap upaya pemerintah dan masyarakat Riau dalam menonjolkan Identitas Melayu Islam. Dengan mengacu pada kerangka konseptual yang telah dijelaskan diatas, secara umum terdapat tiga tahapan upaya yang dilakukan oleh pemerintah dan masyarakat Riau. Tahapan pertama ialah upaya meningkatkan identitas Melayu Islam kepada masyarakat Riau. Pada era Reformasi, elit politik pemerintah provinsi Riau mulai mencoba untuk memperkuat dan menunjukkan identitas mereka yang sebenarnya, dan berbagai wacana dibentuk melalui kebijakan dan disebarluaskan untuk menggambarkan identitas Melayu di Riau (Alfarabi, Antar Venus, Nuryah Asri Syafirah, 2019). LAM didedikasikan untuk melindungi dan memelihara warisan simbol Melayu dan bekerja sama dengan Pemerintah Provinsi Riau dalam memenuhi Visi Misi Riau 2020. Jenis kerjasama lembaga ini dengan Pemerintah dapat dilihat dalam konservasi budaya daerah seperti yang termaktub pada Peraturan Daerah Provinsi Riau No. 1 tahun 2012 dalam Bab IX Pasal 11, LAM Riau yang pada intinya berperan dalam hal (1) inventarisasi aitivitas adat, seni dan budaya serta asset kekayaan, (2) inventarisasi artefat berupa peninggalan bersejarah, dan (3) menyusun rencana kegiatan menyangkut pengelolaan dan pengembangan adat/tradisi Melayu. Kolaborasi antara LAM Riau dan pemerintah daerah merupakan suatu identitas legitimasi yang terlihat dalam proses pembuatan kebijakan, selain itu, LAM Riau telah memiliki peran penting dalam proses pembuatan kebijakan, dalam penyusunan Peraturan Daerah LAM Riau telah terlibat dalam proses pembuatan peraturan daerah, khususnya peraturan daerah mengenai warisan atau praktik-praktik masyarakat melayu Riau (Syu'ib, 2017).

Berkaitan dengan upaya mempertahankan dan mengembangkan budaya Melayu sebagai identitas bersama (kolektif) masyarakat Riau, pemerintah daerah mengeluarkan peraturan (No. 1 tahun 2012 tentang Lembaga Adat Melayu Riau pada bab V Pasal 6) yang berisi tentang tujuan LAM Riau. Lembaga adat ini bertujuan: (1) untuk menggali, membina, melestarikan, memelihara dan mengembangkan nilai-nilai adat dan nilai-nilai sosial budaya sebagai landasan memperkuat dan memperkokoh jati diri masyarakat Melayu, (2) melindungi dan membela hak-hak tradisional dan konstitusional masyarakat adat, dan nilai sosial budaya untuk kepentingan peningkatan kesejahteraan lahiriah dan batiniah masyarakat Melayu Riau, dan (3) mewujudkan masyarakat adat dan nilai-nilai sosial budaya yang maju, adil dan sejahtera dalam tatanan masyarakat madani. Salah satu upaya yang dilakukan adalah kerjasama dalam memperkuat budaya Melayu yang tidal saja terbatas pada kebudayaan yang bersifat soft, tetapi juga yang bersifat hard. Illustasi pada Gambar 2 berikut menunjukkan adanya upaya kuat semua stakeholder dalam membangun budaya Melayu Riau yang berintegritas. Berbagai kerjasama yang terjalin oleh banyak pihak melahirkan rumusan kebijakan seperti halnya Visi Misi Riau 2025 yaitu: "Termujudnya Provinsi Riau sebagai Pusat Perekonomian dan Kebudayaan Melayu dalam lingkungan masyarakat yang agamis, sejabtera labir bathin, di Asia Tenggara Tabun 2025".

Setelah melakukan legitimasi tehadap identitas Melayu Riau, tahap berikutnya ialah upaya masyarakat Riau dalam mendukung berbagai kebijakan pemerintah Riau melalui perlawanan terhadap stigma negatif terhadap budaya Melayu Islam yang telah berlangsung lama. Terdapat stigma mengenai masyarakat Melayu di masa lalu yang dianggap sebagai "pemalas". Anggapan tersebut direspons oleh masyarakat Riau dengan upaya-upaya positif. Tiap-tiap etnik tentu saja 
license

ingin menampilkan citra positif yang bahkan lebih baik daripada etnis lain. Kelompok etnis dengan identitas negatif mencoba yang terbaik untuk menghapus stereotip negatif sehingga citra etnis dapat ditingkatkan. Situasi yang sama dilakukan oleh Orang Melayu Riau pascareformasi yang berusaha keras merubah pandangan negatif kepada etniknya. Salah satunya dengan meluruskan stereotip negatif yang melekat dalam karakter Orang Melayu Riau. Wacana ini dilakukan karna dimasa lalu terdapat pandangan negatif yang dialamatkan pada masyarakat Melayu di masa lalu yaitu 'Melayu itu pemalas dan bukan orang yang pekerja keras' ungkapan ini pada akhirnya menimbulkan suatu paradigma identitas melayu yang negatif. Pandangan negatif tersebut coba dihilangkan melalui wacana Politik identitas Melayu. Paradigma "melayunisasi" kemudian menjadi cara untuk mengubah stigma ini dengan melakukan internalisasi nilai-nilai Islam ke dalam kehidupan masyarakat Melayu. Konsep melayunisasi ditampilkan pada selembayung digedung pemerintah daerah dan lembaga adat yang ada di Riau (Venus et al., 2019).

Penempatan Selembayung di berbagai ruang publik merupakan upaya identifikasi yang dilakukan oleh orang Melayu untuk menunjukkan tuan rumah mereka di Riau. Kebijakan ini diterapkan setelah reformasi euforia kemerdekaan dan perluasan otonomi daerah. Menampilkan identitas Melayu secara harfiah adalah langkah tercepat untuk menunjukkan kehidupan Melayu di Riau. Selembayung adalah tanda visual paling mengesankan untuk ditampilkan, karena terlihat jelas di atap bangunan. Masyarakat Melayu menemukan Selembayung sebagai politik identitas Melayu yang memiliki makna filosofis. Selembayung dapat dilihat dalam dua cara, yaitu Islam dan sosiologis. Pertama, selembayung dapat diposisikan sebagai perwujudan dari rehal (tempat dudukan Al-Qur'an ketika sedang mengaji). Inti dari hal ini adalah keterbukaan komunitas Melayu terhadap penerimaan pendatang. Definisi keterbukaan diperoleh dari sifat pikiran yang terbuka. Transparansi semacam itu adalah gambaran sifat orang-orang Melayu yang, menurut ajaran Islam, ingin tetap berhubungan. Kedua, selembayung dipahami sebagai gambaran adanya hubungan yang kuat di antara manusia (sesama) yang dikenal dalam Islam dengan terma "hablumminnannas". Hal ini dapat dilihat pada pada kayu yang disilangkan. Selain itu, selembayung juga bermakna "bablumminallab", yaitu hubungan baik dengan Allah. Hal ini tercermin dari kayu yang menjulang tinggi lurus ke atas. Intinya, budaya Melayu merupakan budaya yang sangat memelihara hubungan baik di antara manusia, dan hubungan baik dengan Allah. Dalam pespektif sosiologi, selembayung disebut lambang dan ringkasan ciri-ciri orang Melayu (Salam, 2017).

Setelah melalui dua tahap sebelumnya, tahapan terakhir ialah upaya bersama pemerintah dan masyarakat Riau dalam mempromosikan Bahasa Melayu sebagai penegasan akan eksistensi budaya Melayu. Adanya otonomi daerah yang berlaku setelah jatuhnya sistem Orde Baru adalah hal menarik dalam penguatan identitas daerah. Otonomi bahkan didefinisikan sebagai hak belompok suku atau etnis asli di suatu wilayah, sehingga berakibat pada pengabaian hak kelompok suku atau etnis lain yang umumnya merupakan pendatang. Di awal era Reformasi, masyarakat Riau menuntut pemerintah untuk tidak mengabaikan pembangunan di daerah ini. Riau dengan kekayaan alam yang dimiliki masih ketinggal jauh dari daerah lain khususnya Jawa dari segi pembangunan fisik. Bahkan, ada tuntutan dari bawah untuk memberikan otonomi yang seluas-luasnya bagi Riau utnuk mengatur dirinya sendiri. Hal ini memicu semakin mengentalnya identitas kedaerahan Melayu yang memiliki akar sejarah panjang. Hal ini kemudian berdampak langsung pada klaim bahwa Riau harus dipimpin oleh putra/putri daerah sebagai akibat dari akumulasi kekecewaan kepada pemerintah pusat. Berbagai gerakan politik di tingkat lokal pun bermunculan, termasuk di Riau, terutama menyangkut pembuatan kebijakan oleh pemerintah daerah. Masalah umum putra dan putri di wilayah ini terkait dengan kebijakan prioritas atau kebijakan positif yang diterapkan oleh pemerintah daerah untuk menyediakan ruang dan tempat bagi migran etnis dan non-etnis asli dalam kegiatan ekonomi, politik, tata kelola, dan sosial budaya (Asrinaldi, 2018).

Masyarakat Melayu didominasi oleh Muslim. Bahkan, Melayu diidentikkan dengan Islam, dan demikian pula sebaliknya. Baik Islam maupun Melayu memiliki irisan yang tidak bisa dipilah 
license

dan dipisahkan. Hal dapat dilihat pada praktik-praktik sosial masyarakat yang sangat kental dengan budaya Melayu. Pada budaya masyarakat yang memiliki hubungan kuat dengan Islam, pengidentikan bukanlah hal baru. Di berbagai tempat juga dapat ditemukan demikian. Di tanah Bugis misalnya, klaim bahwa Bugis adalah Islam dan sebaliknya sangat kental bahkan hingga saat ini (Jubba et al, 2018; Jubba et al, 2019). Secara kebetulan, antara masyarakat Melayu Riau dan Bugis memiliki hubungan kultural yang kuat. Bahkan, sangat mudah menemukan keturunan Bugis di wilayah Riau hingga sekarang. Pengidentikan sebuah kelompok masyarakat atas agama tertentu juga terjadi misalnya pada masyarakat Dayak di Kalimantan. Dayak adalah Kristen, dan Kristen adalah Dayak. Jika seseorang berpindah agama misalnya, maka ia pun terkeluarkan secara kultural dari masyarakatnya. Fenomena seperti ini menunjukkan bahwa hubungan antara agama dengan budaya sulit dipisahkan.

Beberapa riset telah menyinggung bahwa hubungan Islam dengan Melayu sangat kuat dan sulit dipisahkan. Saat ini, dalam praktik sosial masyarakat Riau selalu dikembalikan acuannya pada Islam. Hal ini merupakan konsekuensi dari pengidentikan tadi. Islam adalah ukuran nilai bagi sikap masyarakat Melayu. Terdapat perasaan yang membanggakan bagi masyarakat Melayu dengan identitas keislamanya. Kualitas Islam dalam aspek Melayu ditunjukkan oleh contoh seseorang yang keluar dari Islam, maka secara otomatis dianggap keluar dari Melayu itu sendiri. Hal yang sama juga berlaku ketika seseorang yang mengaku Islam sehingga secara umum masyarakat akan mengatakan orang tersebut telah menjadi Melayu.

Politik uniformitas di era Orde Baru sangat efektif menekan berbagai identitas lokal yang beragam. Selain Bahasa, pakaian juga menjadi perhatian rezim kala itu. Semua harus seragam, demikian prinsip sederhananya yang dianut kala itu. Dampaknya adalah kebudayaan-kebudayaan lokal tergerus dan larut mengikuti budaya uniformitas tadi. Bahkan, ketika itu dominasi kultur di Indonesia sangat jawaisme. Pembangunan pun berpusat di Jawa sehingga daerah-daerah lain "terlupakan". Pasca keruntuhan Orde Baru, terjadi gelombang baru yang mengusung kesamaan hak kultur anak bangsa. Berbagai identitas daerah muncul kepermukaan dan berusaha tampil dengan kekhasannya masing-masing. Penguatan identitas kedaerahan semakin mendapat ruang seiring dengan kebijakan desentralisasi. Kekusasaan tidak lagi tersentral di pusat, tetapi telah disebar ke daerah-daerah dengan Batasan-batasan tertentu. Di kalangan masyarakat Melayu, berbahasa Melayu merupakan sebuah kebanggaan dan sebagai bentuk upaya mengembalikan "marwah" budaya yang selama ini tenggelam. Melalui Bahasa Melayu pula, identitas kemelayuan seseorang dapat terlihat.

Bahasa Melayu dapat dipahami dalam tiga sudut pandang, yaitu filosofis, praktis, dan politis. Pertama, secara filosofis, penggunaan bahasa Melayu (termasuk dialeknya) memiliki kandungan makna tersendiri. Identitas Kemelayuan di Riau dapat dilihat, salah satunya, dari sudut pandang ini. Secara filosofis, Bahasa Melayu merupakan akibat dari keinginan dan pilihan orang Melayu atas Islam sebagai pilihan keyakinannya. Keduanya pun tidak bisa dipisahkan karena telah terinternalisasi dalam kehidupan dan praktik keseharian mereka. Dalam sejarahnya, kehadiran Islam berdampak pada seluruh budaya bangsa Melayu, termasuk penggunaan bahasa. Petuahpetuah atau ujaran-ujaran yang disampaikan oleh Raja Ali Haji dalam Gurindam Dua Belasm misalnya, memuat ujaran bagi masyarakat mengenai apa yang seharusnya dilakukan khususnya dalam bersikap dan bertingkah-laku sesuai dengan adat Melayu dan hal tersebut sangat islami. Dalam Gurindam Dua Belas yang memuat dua belas pasal misalnya ditemukan petuah atau ujaran luhur ini.

Jika bendak mengenal orang yang berbangsa

Lihat kepada budi dan bahasa 
This is an open access article under the CC-BY-SA Vol 7 No 1 (2021), pp.89-98

license

\author{
Jika hendak mengenal orang yang berbahagia \\ sangat memeliharakan yang sia-sia \\ Jika hendak mengenal orang mulia \\ Lihatlah kepada kelakuan dia \\ Jika hendake mengenal orang yang berilmu \\ Bertanya dan belajar tidaklah jemu \\ Jika bendak mengenal orang yang berakal \\ Di dalam dunia mengambil bekal \\ Jika bendak mengenal orang yang baik, perangai \\ Libatlah pada ketika bercampur dengan orang ramai
}

Bait Gurindam di atas, memberikan ajaran bahwa seorang dalam bersikap dan bertingkah laku sebagai adat istiadat Budaya Melayu. Ajaran tersebut adalah dalam berbangsa atau bersuku atau berkelompok atau berorganisasi seseorang harus memiliki budi dan bahasa yang baik. Budi dan bahasa yang baik sudah dicontohkan dalam agama dan adat istiadat. Apalagi adat istiadat Budaya Melayu, nilai adat istiadat diambil dari nilai-nilai agama (Mohamad Zainuri, 2017). Secara filosofis, dalam Bahasa Melayu termaktub nilai-nilai yang berkaitan dengan akhlak dan budi pekerti mulia yang dapat dirasakan dari kelembutan dialek bahasanya.

Kedua, tentang bahasa Melayu dilihat dari praktis atau penggunaan kata. Bahasa manapun sarat dengan makna dan simbol. Bahasa Melayu pun demikian, penuh dengan simbol-simbol. Pada frasa-frasa dalam Bahasa Melayu sering tidak bersifat direktif atas apa yang dikatakan, tetapi merujuk pada perumpamaan-perumpamaan sehingga membutuhkan kepekaan yang tinggi bagi pengguna dan pendengarnya. Simbolisme di Melayu terkait dengan disposisi yang tenang dan keragaman perasaan dalam budaya Melayu, yang mencegah konflik. Pada banyak frasa, sangat jelas bagaimana Bahasa ini menjunjung tinggi perasaan seseorang (lawan bicara). Pada salah satu baik Gurindam Dua Belas sebagaimana yang kutip oleh Tenas Effendy (2013) tentang anjuran untuk bekerja dalam amanah disebutkan:

\title{
Apabila bekerja memegang amanah, Orang percaya menjaubkan fitnah Apabila bekerja tiada lalai Hasilnya tidak akan terbangkalai
}

Bait di atas menegaskan bahwa amanah merupakan kunci keberhasilan dalam sebuah pekerjaan. Bahkan, sangat ditekankan bagi siapa saja untuk bekerja dalam bingkai kejujurna yang tinggi. Sebab, jika kejujuran tidak ditegakkan maka pekerjaannya pun tidak bermakna (bermanfaat). Di sini dapat dilihat bahwa nilai Islam dan Bahasa Melayu sangat erat kaitannya. Keduanya sangat menekankan pada arti penting dari sebuah kejujuran yang menjadi pilar keberhasilan.

Sudut pandang ketiga dalam memahami bahasa Melayu adalah bahasa (dialek) merupakan alat politik. Sekali lagi, sebuah bahasa tidak saja berfungsi sebagai alat komunikasi untuk menjalin pembicaraan dengan orang lain. Akan tetapi, bahasa juga memilik fungsi label atau penanda bagi seseorang atau kelompok masyarakat. Bahasa Melayu Riau sebagai akar bahasa nusantara sangat politis. Sebab, bahasa ini selalu dijadikan acuan. Fakta bahwa Bahasa Melayu adalah asal-muasal Bahasa Indonesia tidak bisa terbantahkan. Dalam praktinya, Bahasa Melayu Riau terbagi menjadi dua dialek. Bahasa Melayu Riau dengan akhiran " $e$ " dan bahasa dengan akhiran "o". Dialek Bahasa Melayu sangat banyak, ada yang mengatakan 87 dialek yang tersebar di pulau Sumatera dan beberapa daerah lain. Setiap dialek dipraktikkan oleh kelompok masyarakat sendiri yang juga mengusung misi tertentu yang tidak hanya terbatas pada media komunikasi, tetapi juga untuk menunjukkan identitas diri dan daerah masing-masing. 
license

\section{Kesimpulan}

Upaya pemerintah dan masyarakat Riau dalam menonjolkan identitas Melayu di Provinsi Riau dapat dilihat dari tiga tahapan konstruksi identitas. Pertama, Identitas Legitimasi Melayu Riau melalui Lembaga Adat Malaya Riau (LAM) yang didedikasikan untuk melindungi dan memelihara tradisi simbol Malaya dan berkolaborasi dengan Pemerintah Provinsi Riau dalam memenuhi Visi Misi Riau 2020. Kedua, Identitas Resisten Melayu Riau dilakukan ketika terdapat pandangan negatif yang disematkan pada melayu di masa lalu sebagai masyarakat pemalas. Stigma ini pada akhirnya menimbulkan suatu paradigma identitas melayu yang negatif secara umum. Berbagai upaya dilakukan hingga saat ini untuk mengubah persepsi tersebut melalui internalisasi nilai-nilai Islam ke dalam aspek-aspek kehidupan masyarakat Melayu Riau yang sering disebut 'Melayunisasi'. Konsep ini ditampilkan pada selembayung digedung pemerintah daerah dan lembaga adat yang ada di Riau. Ketiga, Identitas Proyek Melayu Riau terlihat dari pengidentifikasian Melayu adalah Islam dan sebaliknya adalah salah satu strategi untuk menghapus stigma yang sebelumnya dialamatkan tersebut.

Konstruksi identitas Melayu Riau yang sangat kental dengan nilai-nilai Islam menjadi titik kompromi. Baik Melayu maupun Islam memiliki domain masing-masing yang pada akhirnya dapat dipertemukan dalam berbagai arena dan kondisi seperti yang dapat ditemukan pada design bangunan dans sebagainya. Apa yang terjadi selama ini, khususnya menyangkut bagaimana identitas Melayu Riau ditempatkan pada posisi yang berintegritas merupakan langkah yang strategis untuk mengangkat kearifan lokal agar semakin mengemuka. Studi ini, selain memperlihatkan adanya upaya dan komitmen kuat dari semua kalangan dalam mengkonstruk identitas budaya bangsa yang mulai pudar, juga menjadi indikator kuat atas adanya semangat nasionalisme yang tidak pernah padam di kalangan masyarakat Indonesia. Oleh karena itu, studi ini merekomendasikan perlunya dilakukan terobosan-terobosan baru yang lebih progresif dalam rangka menjamin keberlangsungan budaya daerah yang telah terbukti menjadi salah satu pilar penting terwujudnya kohesi sosial yang semakin kuat saat ini.

\section{Referensi}

Abdullah, A. (2017). Membaca Komunikasi Politik Gerakan Aksi Bela Islam 212: Antara Politik Identitas dan Ijtihad Politik Alternatif. Jurnal An-Nida' (Pemikiran Islam), 41(2), 202-212.

Abdullah, I. (2017). Glokalisasi Identitas Melayu: Potensi dan Tantangan Budaya dalam Reproduksi Kemelayuan. Manhaj: Jurnal Penelitian dan Pengabdian Masyarakat, 6 (2), 1-7.

Affandi, S. A. (2018). Kapabilitas Lembaga Adat Melayu Riau dalam Mewujudkan Visi Misi Riau 2020. Tesis. $78-150$.

Albi Anggito, J. S. (2018). Metodologi Penelitian Kualitatif. Sukabumi: Jejak.

Alfarabi. (2019). Simbol Eksistensi Identitas Etnik Melayu Riau di Pekanbaru. Jurnal Ilmu Sosial dan Humaniora, 3(1), 67-77.

Alfarabi, Antar Venus, N. A. S. \& N. E. S. (2019). Elite Lokal dan Upaya Pembentukan Wajah Baru Identitas Melayu di Indonesia Pascareformasi. Akademika: Journal of Southeast Asia Social Sciences and Humanities, 89(3), 143-154.

Alfarabi, Antar Venus, Nuryah Asri Syafirah, N. E. S. (2019). Media Identitas Melayu Pascareformasi di Indonesia. International Journal of Multicultural and Multireligious Understanding, 6(1), 21-31.

Asrinaldi, A. (2018). Dimensi Kekuasaan Penghulu Adat Melayu Riau dalam Pelaksanaan Demokrasi Lokal. Jantro: Jurnal Antropologi Isu-isu Sosial Budaya, 20(1), 57-69.

Effendy, T. (2013). Tunjuk Ajar Melayu dalam Pantun, Gurindam, Seloka, Syair, dan Ungkapan. Pekanbaru: Tenas Effendy Foundation. 
license

Erman, M. A. (2018). Politik Identitas dan Negara Bangsa Di Riau. Nabkoda: Jurnal Ilmu Pemerintahan, 17(1), 1-13.

Habibi, M. (2017). Analisis Politik Identitas di Indonesia. (March), 1-22. Https://Doi.Org/10.13140/Rg.2.2.16590.66887

Hapsa, E. P. P. (2019). Relasi Kuasa Identitas Etnis di Lembaga Legislatif Periode 2014-2019. JGP: Journal of Government and Public Policy, 3(1), 125-146.

Hemay, I., \& Munandar, A. (2015). Politik Identitas dan Pencitraan Kandidat Gubernur terhadap Perilaku Pemilih. Politik: Jurnal Kajian Politik dan Masalah Pembangunan, 12(1), 1737-1748.

Hermawan, I. (2019). Metodologi Penelitian Pendidikan Kuantitatif, Kualitatif Dan Mexod Method. Kuningan: Hidayatul Quran Kuningan.

Heywood, A. (2014). Politik. Yogyakarta: Pustaka Pelajar.

Jaya, A. C. (2019). Konsep Nation-State Dalam Pemikiran Ideologi Politik Melayu Islam Pada Abad Ke-19 M (Studi Pemikiran Abdullah Bin Abdul Kadir Munsyi (1787-1854). Jurnal Tapis: Jurnal Teropong Aspirasi Politik Islam 15 (1), 1-25.

Jubba, H., Pabbajah, M., Prasodjo, Z. H., \& Qodir, Z. (2019). The future relations between the majority and minority religious groups, viewed from Indonesian contemporary perspective: A case study of the coexistence of Muslims and the Towani Tolotang in Amparita, South Sulawesi. International Journal of Islamic Thought, 16(2), 13-23. https://doi.org/10.24035/ijit.16.2019.002

Jubba, H., Rustan, A. S., \& Juhansar, J. (2018). Kompromi Islam dan Adat pada Praktik Keagamaan Muslim Bugis di Sulawesi Selatan. JSW: Jurnal Sosiologi Walisongo, 2 (2), 137-148. https://doi.org/10.21580/jsw.2018.2.2.2865

M.Zainuddin. (2018). Mekanisme Lembaga Adat Melayu Riau Dalam Melestarikan Wisata Budaya Di Provinsi Riau. Jurnal Agregasi, 6(1), 91-107.

Mohamad Zainuri, M. (2017). Budaya Melayu Berintegritas. In D. S. Suparman (Ed.), Modul Diseminasi Gugus Depan Integritas, 1-17. Kota Pekanbaru Provinsi Riau: Pemerintah Provinsi Riau.

Prayetno. (2016). Menguji Hak Politik Dalam Kontestasi Politik; Analisis Terbadap Politik Identitas Etnis Di Desa Perdamaian, Kecamatan Binjai, Kabupatan Langkat. Vii(2), 39-54.

Ris'an Rusli, Y. (2018). Relevansi Dan Kontinuitas Pemikiran Islam Klasik Dalam Intelektualisme Islam Melayu Nusantara. 2(November), 187-197. https://Doi.Org/10.15575/Jw.V3i2.3582

Rozi, S. (2018). Nasionalisme Demokratisasi Dan Sentimen Primordialisme Di Indonesia. Jurnal Penelitian Politik, 6(1), 75-84.

Salam, N. E. (2017). Penetapan Simbol Arsitektur Perumahan Masyarakat Riau (Selembayung) Sebagai Strategi dalam Melestarikan Budaya. Prosiding $2^{\text {th }}$ Celscitech-UMRI, 2, 29-37.

Salim, K. (2015). Politik Identitas di Maluku Utara. Politik: Jurnal Kajian Politik dan Masalah Pembangunan, 11(2), 1667-1678.

Sanusi, I. (2017). Globalisai Melayu : Peluang dan Tantangan Membangun Identitas Melayu dalam Konteks Modernitas. Khazanah, 1(1), 39-57.

Syamsuadi, A. (2018). Membangun Demokrasi Pemerintahan di Riau dalam Perspektif Budaya Melayu. Jurnal Dinamika Pemerintahan, 1(1), 1-10.

Syu'ib. (2017). Lembaga Adat Melayu Riau Periode 2012-2017 dalam Menegakkan Identitas Kolektif Masyarakat Riau. Jurnal Online Mahasiswa Fisipol Universitas Riau, 4(2), 1-16.

Ulum, B., Jannah, S. R., \& Arifullah, M. (2017). Hegemoni Sosial Dan Politik Identitas Putra Daerah Jambi, Al-Daulah: Jurnal Hukum dan Peundangan Islam, 7(1), 225-249.

Venus, A., Syafirah, N. A., \& Salam, N. E. (2019). Stereotip, Melayu, Etnik, Reformasi, Pendatang. Jurnal Managemen Komunikasi, 3(2), 131-141.

Yosi Malasari, C. D. (2017). Budaya Adat Pengantin Melayu Riau Dalam Pengembangan Budaya Kewarganegaraan. Humanika, 24(1), 11-23. 
Copyright (C) 2021, Hasse Jubba, Muhammad Rafi, Zuly Qodir

This is an open access article under the CC-BY-SA license
ISSN 2088-8090 (Print) ISSN 2597-6648 (Online) Sospol: Jurnal Sosial Politik Vol 7 No 1 (2021), pp.89-98

Zed, M. (2015). Hubungan Indonesia-Malaysia: Perspektif Budaya dan Keserumpunan Melayu Nusantara. Tingkap: Jurnal Ilmu-ilmu Sosial Budaya dan Ekonomi, 11(2), 140-159. 